\title{
Some Pitfalls in Federal Practice
}

\author{
Preliminary
}

$\mathrm{T}$

HE constant and repeated failure of the profession to observe certain rules of practice in cases in the federal courts, resulting in failure to have cases decided upon their merits, has become so prevalent as to justify more than passing remark. Most attorneys are educated in the law with particular reference to the laws of the states, and they are particularly instructed in practice in the state courts. Many practitioners never practice in the federal courts, and many more seldom do so. After practic!ing for two years in the state courts, they are automatically admitted to the federal courts, with no special inquiry as to their qualifications, particularly with reference to the more or less intricate system of practice prevailing in those courts. It is not the purpose of this article to present any treatise on federal practice, but it is thought that a few rules have become such constant sources of error, that by calling attention to them in this way these errors may be avoided and the young lawyers in particular may be incited to delve even further into the possible pitfalls that await them in a journey through the procedure of the Federal Courts.

I.

\section{WAIVER OF JURY}

Under the state practice the waiver of a trial by jury may be accomplished either formally or informally, and the result on the case is not affected by the manner in which the waiver is accomplished. A practitioner familiar with that practice may naturally think the same liberality prevails in the federal courts. The federal statute permits a jury to be waived only by stipulation in writing filed with the clerk. ${ }^{2}$ If the case is tried without a jury, and without a waiver in that manner, the case on appeal is deemed to have been tried by the judge as an arbitrator, and no errors can be reviewed, except such as appear in the pleadings and judgment. Errors oc-

113 U. S. Stats. at L. 501, U. S. Rev. Stats. § 649, U. S. Comp. Stats. (1918) § 1587, 6 Fed. Stats. Ann. (2d ed.) 130. 
curring at the trial and embodied in a bill of exceptions cannot be considered on appeal. ${ }^{2}$

Moreover, in order that the case may be reviewed, the record on appeal must affirmatively show that the waiver was accomplished in the statutory manner; and even a recital in the judgment that a jury was $d u l y$ waived is not sufficient. ${ }^{3}$

II.

REQUEST FOR FINDINGS

If a case is tried by the court without a jury, it is not sufficient that the record contains no finding on a particular issue, but in order to take advantage of this fact on writ of error, the court must have been requested to make a finding thereon. ${ }^{4}$

2 In the following cases a right of review was lost by failure to observe this rule: James Dickinson Co. v. Seimer (C. C. A. 7th Circ. 1926) 12 F. (2d) 772; Hecht v. Alfaro (C. C. A. 9th Circ. 1926) 10 F. (2d) 464; Twist v. Prairie Oil Co. (C. C. A. 8th Circ. 1925) 6 F. (2d) 347; Nat. City Bank v. Kimball Bank (C. C. A. 8th Circ. 1924) 2 F. (2d) 461 ; Bank of Waterproof v. Fidelity Co. (C. C. A. 5th Circ. 1924) 297 Fed. 217; U. S. v. One Ford Sedan (C. C. A. 5th Circ. 1924) 297 Fed. 830; Firestone v. M'Cutcheon (C. C. A. 8th Circ. 1922) 284 Fed. 220; American Steel Co. v. Hart (C. C. A. $2 d$ Circ. 1922) 285 Fed. 322; U. S. v. Nat. City Bank (C. C. A. 2d Circ. 1922) 281 Fed. 754; City of Cleveland v. Walsh (C. C. A. 6th Circ. 1922) 279 Fed. 57; Cross State Land Co. v. Pruett (C. C. A. 5th Circ. 1922) 278 Fed. 143; Ford v. Grimmett (C. C. A. 5th Circ. 1922) 278 Fed. 140; Commissioners of Lafayette County v. St. Louis Ry. Co. (C. C. A. 8th Circ. 1922) 265 Fed. 524 (aff'd 257 U. S. 547, 66 L. Ed. 364, 42 Sup. Ct. Rep. 250); U. S. v. Blake (C. C. A. 6th Circ. 1922) 279 Fed. 71; McClay v. Fleming (C. C. A. 8th Circ. 1921) 271 Fed. 472; Dendy v. So. Pine Co. (C. C. A. 5th Circ. 1920) 269 Fed. 13; Ill. Surety Co. v. U. S. (C. C. A. 2d Circ. 1916) 229 Fed. 527.

${ }^{3}$ Spalding v. Manasse (1889) 131 U. S. 65, 33 L. Ed. 86, 9 Sup. Ct. Rep. 649, Dundee Mfg. Co. v. Hughes (1888) 124 U. S. 157,31 L. Ed. 357, 8 Sup. Ct. Rep. 377; Imperial Life Ins. Co. v. Newcomb (C. C. A. 8th Circ. 1894) 62 Fed. 97; Bond v. Dustin (1884) 112 U. S. 604, 28 L. Ed. 835, 5 Sup. Ct. Rep. 296; U. S. Fidelity Co. v. Whittaker (C. C. A. 9th Circ. 1925) . 8 F. (2d) 455, 458; Columbus Compress Co. v. U. S. Fidelity Co. (C. C. A. 5th Circ. 1911) 186 Fed. 487; Erkel v. U. S. (C. C. A. 9th Circ. 1909) 169 Fed. 623; Shields v. Mongollon Co. (C. C. A. 9th Circ. 1905) 137 Fed. 539; City of Defiance v. Schmidt (C. C. A. 1st Circ. 1903) 123 Fed. 1; Ham v. Edgell (C. C. A. 5th Circ. 1901) 106 Fed. 820; Abraham v. Levy (C. C. A. 5th Circ. 1896) 72 Fed. 124; Duncan Y. A. T. \& S. F. Ry. (C. C. A. 9th Circ. 1896) 72 Fed. 808; Cudahy v. Sioux Nat. Bank (C. C. A. 8th Circ. 1895) 69 Fed. 782; Dietz v. Lymer (C. C. A. 8th Circ. 1894) 63 Fed. 758; U. S. v. Carr (C. C. A. 8th Circ. 1894) 61 Fed. 802; Rush v. Newmau (C. C. A. 8th Circ. 1893) 58 Fed. 158; Branch v. Texas Co. (C. C. A. 5th Circ. 1893) 53 Fed. 849; Smith v. Weeks (C. C. A. 1st Circ. 1893) 53 Fed. 758.

In the following cases failure to request finding in the trial court resulted in failure to obtain a review of the case on the merits: Fleischmann Construction Co. v. U. S. (1926) 270 U. S. 349, 70 L. Ed., Adv. Ops. 254, 46 Sup. Ct. Rep. 284; Cooper v. Omohundro (1874) 86 U. S. 65, 22 L. Ed, 
A similar rule applies in a case tried by jury. If it is desired to have the question whether the evidence is sufficient to support the verdict passed upon on writ of error, a request must be made at the conclusion of the case for a peremptory instruction to the jury. ${ }^{5}$

47; G. Ansinck Co. v. Springfield Grocer Co. (C. C. A. 8th Circ. 1925) 7 F. (2d) 855; Jenkins y. Boyd (C. C. A. 9th Circ. 1925) 6 F. (2d) 844; Geiger v. Tramp (C. C. A. 8th Circ. 1923) 291 Fed. 353; Pennok Oil Co. v. Roxana Co. (C. C. A. 8th Circ. 1923) 289 Fed. 416; Bank of Italy v. Romeo Co. (C. C. A. 9th Circ. 1923) 287 Fed. 5; Flood v. Bates (C. C. A. 7th Circ. 1922) 283 Fed. 364; Ewart v. Thompson (C. C. A. 8th Circ. 1922) 281 Fed. 449; Texas etc. Co. v. Robinson (C. C. A. 5th Circ. 1921) 272 Fed. 453; Chicago Bonding Co. v. City of Pittsburg (C. C. A. 8th Circ. 1921) 271 Fed. 678; Crowell v. Panhandle Co. (C. C. A. 8th Circ. 1921) 271 Fed. 129 ; U. S. v. A. T. \& S. F. Ry. (C. C. A. 8th Circ. 1921) 270 Fed. 1; Dendy v. So. Pine Lumber Co. (C. C. A. 5th Circ. 1920) 269 Fed. 13; Pabst v. Clemens Horst Co. (C. C. A. 9th Circ. 1920) 264 Fed. 909; Northern Idaho Power Co. v. Jordan Co. (C. C. A. 9th Circ. 1920) 262 Fed. 765; First Nat. Bank of Casselton v. Nat. City Bank of Chicago (C. C. A. 8th Circ. 1919) 261 Fed. 912; Kindred v. Black (C. C. A. 8th Circ. 1919) 257 Fed. 302; Raymer v. Netherwood (C. C. A. 7th Circ. 1919) 257 Fed. 284; Caldwell v. Blodgett (C. C. A. 8th Circ. 1919) 256 Fed. 744; Turner v. Schaeffer (C. C. A. 6th Circ. 1918) 249 Fed. 654; Security Nat. Bank v. Old Nat. Bank (C. C. A. 8th Circ. 1917) 241 Fed. 1; C. M. \& St. Paul Ry. v. Hormel Co. (C. C. A. 8th Circ. 1917) 240 Fed. 381; Smith v. Kingfalfa Mills (C. C. A. 8th Circ. 1916) 237 Fed. 82; Rutnan v. Johnson \& Johnson (C. C. A. 3 di Circ. 1916) 231 Fed. 369; Phoenix v. Dittmar (C. C. A. 9th Circ. 1915) 224 Fed. 892; Wear v. Imperial Co. (C. C. A. 8th Circ. 1915) 224 Fed. 60; Dunsmuir v. Scott (C. C. A. 9th Circ. 1914) 217 Fed. 200; Tiernan v. Chicago Iife Ins. Co. (C. C. A. 8th Circ. 1914) 214 Fed. 238, 241; Eastern Oil Co. v. Holcomb (C. C. A. 8th Circ. 1914) 212 Fed. 126, 130; Penn. Casualty Co. v. Whiteway (C. C. A. 9th Circ. 1914) 210 Fed. 782; Sandeen v. Scott (C. C. A. 8th Circ. 1913) 205 Fed. 252; Seep v. Feris Haggarty Co. (C. C. A. 8th Circ. 1912) 201 Fed. 893; Gibson v. Luther (C. C. A. 8th Circ. 1912) 196 Fed. 203, 205; Felker v. First Nat. Bank (C. C. A. 8th Circ. 1912) 196 Fed. 200, 202; Bell v. U. P. Ry. (C. C. A. 8th Circ. 1912) 194 Fed. 366, 368; Jackson v. Mutual Life Ins. Co. (C. C. A. 8th Circ. 1911) 186 Fed. 447, 449; Marinette Sawmill Co. v. Scofield (C. C. A. 7th Circ. 1909) 174 Fed. 562; Allen v. Knott (C. C. A. 7th Circ. 1909) 171 Fed. 76; Kelly v. Ophir Co. (C. C. A. 8th Circ. 1909) 169 Fed. 598; U. S. Fidelity \& Guaranty Co. v. Bd. of Comm'rs. (C. C. A. 8th Circ. 1906) 145 Fed. 144; Streeter v. Sanitary District (C. C. A. 7th Circ. 1904) 133 Fed. 124; York v. Washburn (C. C. A. 8th Circ. 1904) 129 Fed. 564; City of Ogden v. Weaver (C. C. A. 8th Circ. 1901) 108 Fed. 564; McMaster v. N. Y. Ins. Co. (C. C. A. 8th Circ. 1899) 99 Fed. 856.

- See Sandeen v. Tschider (C. C. A. 8th Circ. 1913) 205 Fed. 252, 4th headnote: "Introduction of evidence in his own behalf by the defendant after denial of his motion to dismiss is a waiver of the error, if any, in the ruling of his motion." Also, on this point, see Mechanics Ins. Co. v. Hoover Co. (C. C. A. 8th Circ. 1910) 182 Fed. 590. See also, Allen v. Cartan \& Jeffery Co. (C. C. A. 8th Circ. 1925) 7 F. (2d) 21, for a discussion of the act of Feb. 26, 1919, in which the conclusion is reached that the rule as to motion and exception remain unchanged by this act. See also, Howe v. Parker (C. C. A. 8th Circ. 1917) 190 Fed. 738, 746, wherein this same rule as to motion and exception is applied to trials before the Secretary of the Interior or any quasi-judicial body. See also, St. Louis Packing Co. v. Houston (C. C. A. 8th Circ. 1917) 242 Fed. 337, on the same point.

In the following cases failure to ask for a peremptory instruction to the jury at the conclusion of the case prevented any review in the appellate court: 


\section{III.}

\section{EXCEPTIONS TO INSTRUCTIONS}

Under the state practice instructions to the jury are deemed excepted to; but such is not the rule in the federal courts. On the contrary the instructions not only must be excepted to, but those exceptions must be noted in the presence of the jury. This requirement can not be waived by counsel or even by the court."

IV.

\section{ANSWer UNDER OATH IN Equity SuIt}

Another rule in federal practice of which practitioners run afoul is that if the bill is verified, or if unverified and an answer under oath is not waived, and the answer is verified and is made on

Steil v. Holland (C. C. A. 9th Circ. 1925) 3 F. (2d) 776; U. S. v. McDonald (C. C. A. 5th Circ. 1923) 293 Fed. 433 ; Bank of Italy v. Romeo Co. (C. C. A. 9th Circ. 1923) 287 Fed. 5; Brolaski v. U. S. (C. C. A. 9th Circ. 1922) 279 Fed. 1; Penn. Casualty Co. v. Whiteway (C. C. A. 9th Circ. 1914) 210 Fed. 782; Royce v. Del. Ry. (C. C. A. 2d Circ. 1913) 203 Fed. 467; Mexico Land Co. v. Larkin (C. C. A. 8th Circ. 1912) 195 Fed. 495; Sun Pub. Co. v. Lake Erie Co. (C. C. A. 6th Circ. 1907) 157 Fed. 80; Walton v. Wild Goose Mining Co. (C. C. A. 9 th Circ. 1903) 123 Fed. 209; Dorsey v. U. S. (C. C. A. 8th Circ. 1900) 101 Fed. 746; City of Lincoln v. Sun Vapor Co. (C. C. A. 8th Circ. 1894) 59 Fed. 756.

EIn the following cases a review was denied for failure to observe this requirement: Hickory v. U. S. (1894) 151 U. S. 303, 38 I. Ed. 170, 14 Sup. Ct. Rep. 334; Griffin Groc. Co. v. Richardson (C. C. A. 8th Circ. 1926) 10 F. (2i1) 467; Edwards v. U. S. (C. C. A. 8th Circ. 1925) 7 F (2d) 357; Central Vt. Ry. v. Howard (C. C. A. 2d Circ. 1924) 297 Fed. 566; Rumely v. U. S. (C. C. A. $2 d$ Circ. 1923) 293 Fed. 532; Rosenblatt v. U. S. (C. C. A. $2 d$ Circ. 1921) 271 Fed. 435 ; Central R. R. Co. v. Sharkey (C. C. A. 2d Circ. 1919) 259 Fed. 144; Am. Issue Pub. Co. v. Sloan (C. C. A. 6th Circ. 1917) 248 Fed. 251; McClendon v. U. S. (C. C. A. 8th Circ. 1916) 229 Fed. 523, 5:27; Copper River Co. v. Reader (C. C. A. 9th Circ. 1914) 211 Fed. 280; Star Co. v. Madden (C. C. A. 2d Circ. 1911) 188 Fed. 910; Wells Fargo Co. v. Zimmer (C. C. A. 8th Circ. 1911) 186 Fed. 130; Bidwell v. Douglas Co. (C. C. A. 2d Circ. 1910) 183 Fed. 93; Mann v. Dempster (C. C. A. 2d Circ. 1910) 179 Fed. 837; Berwind White Co. v. Firment (C. C. A. 2d Circ. 1909) 170 Fed. 151; Penn. Co. v. Whitney (C. C. A. 6th Circ. 1909) 169 Fed. 572; Klaw v. Life Pub. Co. (C. C. A. 2d Circ. 1906) 145 Fed. 134; Tromp v. Wm. Cramp Co. (C. C. A. 2d Circ. 1906) 143 Fed. 867; Erie F. R. Co. v. Little (C. C. A. 2d Circ. 1904) 128 Fed. 546; Hindman v. First Nat. Bank (C. C. A. 6th Circ. 1902) 112 Fed. 931; Sterenberg v. Mailhos (C. C. A. 5th Circ. 1900) 99 Fed. 43; Com. Travellers' Ass'n. v. Fulton (C. C. A. 2d Circ. 1897) 79 Fed. 423; New Eng. Furn. etc. Co. v. Catholicon Co. (C. C. A. 8th Circ. 1897) 79 Fed. 294; Merchants Bank v. McGraw (C. C. A. 9th Circ. 1896) 76 Fed. 930; St. Louis Ry. v. Spencer (C. C. A. 8th Circ. 1895) 71 Fed. 95; Park v. Bushnell (C. C. A. 2d Circ. 1894) 150 Fed. 583. 
personal knowledge, the answer can only be overcome by the testimony of two witnesses, or one witness and circumstances equivalent to one witness. To avoid this result the bill should be unverified and an answer under oath should be waived. This rule has an ancient origin and seems to be unaffected by the new equity rules. ${ }^{7}$

\section{CoNCLUSION}

If these instances were extended further this article might become a treatise on federal practice, which is not intended. All that is desired is to call attention to these highly technical requirements, which are so often the cause of our undoing, in the hope that those reading this comment and learning of these rules for the first time may be tempted to further explore this important subject.

San Francisco, California.

Edward F. Treadwell.

7 Demarest v. Winchester Repeating Arms Co. (Dist. Ct. Conn. 1919) 257 Fed. 162; Watts v. Crabb (C. C. A. 9th Circ. 1919) 257 Fed. 717, 169 C. C. A. 5; Wilcox v. El Banco (C. C. A. 1st Circ. 1918) 255 Fed. 442, 166 C. C. A. 518. This question has not been passed upon by the United States Supreme Court. In view of the fact that the equity rules provide that the complaint "should" be verified where preliminary relief is desired, it is difficult to see how this rule can longer prevail. 